\title{
Antibacterial mechanism of rhodomyrtone involves the disruption of nucleoid segregation checkpoint in Streptococcus suis
}

\section{Apichaya Traithan}

Graduate Program in Biomedical Sciences, Faculty of Allied Health Sciences, Thammasat University

\section{Pongsri Tongtawe}

Graduate Program in Biomedical Sciences, Faculty of Allied Health Sciences, Thammasat University Jeeraphong Thanongsaksrikul

Graduate Program in Biomedical Sciences, Faculty of Allied Health Sciences, Thammasat University

Supayang Voravuthikunchai

Prince of Songkla University Faculty of Science and Natural products

Potjanee Srimanote ( $\sim$ Psrimanote01@yahoo.com.au )

Thammasat University

\section{Original article}

Keywords: Streptococcus suis; Cell division; Rhodomyrtone; Cell division defects

Posted Date: May 14th, 2020

DOl: https://doi.org/10.21203/rs.3.rs-27637/v1

License: (c) (i) This work is licensed under a Creative Commons Attribution 4.0 International License. Read Full License

Version of Record: A version of this preprint was published at AMB Express on June 8th, 2020. See the published version at https://doi.org/10.1186/s13568-020-01047-x. 


\section{Abstract}

Rhodomyrtone has been recently demonstrated to possess a novel antibiotic mechanism of action against Gram-positive bacteria which involves multiple targets, resulting in the interference of several bacterial biological processes including cell division. The present study aims to closely look at the downstream effect of rhodomyrtone treatment on nucleoid segregation in Streptococcus suis, an important zoonotic pathogen. Minimum inhibition concentration (MIC) and minimum bactericidal concentration (MBC) values of rhodomyrtone against recombinant $S$. suis ParB-GFP, a nucleoid segregation reporter strain, were 0.5 and $1 \mu \mathrm{g} / \mathrm{ml}$, respectively, equivalent to the potency of vancomycin. Using fluorescence live-cell imaging, we demonstrated that rhodomyrtone at $2 \times$ MIC caused incomplete nucleoid segregation and septum misplacement, leading to the generation of anucleated cells. FtsZ immune-staining of rhodomyrtone-treated $S$. suis for 30 min revealed that although large amount of FtsZ was trapped in the region of high fluidity membrane, it appeared to be able to polymerize to form a complete Z-ring. However, the Z-ring was shifted away from midcell. Transmission electron micrograph further confirmed disruption of nucleoid segregation and septum misplacement at 120 min following rhodomyrtone treatment. Asymmetric septum formation resulted in either generation of minicells without nucleoid, septum formed over incomplete segregated nucleoid (guillotine effect), or formation of multiconstriction of Z-ring within a single cell. This finding spotlights on antibacterial mechanism of rhodomyrtone involves the early stage in bacterial cell division process.

\section{Introduction}

Streptococcus suis is Gram-positive bacteria causing severe systemic infections in young and weaning piglets (Halaby et al. 2000; Lun et al. 2007). Zoonotic transmission of this pathogen to human occurs via direct contact with the sick pigs or consumption of contaminated meat and pork products (Segura et al. 2014; Wertheim et al. 2009). Similar to Streptococcus pneumoniae infections, penicillin and ampicillin previously were the mainstay of treatment of S. suis infections (Lakkitjaroen et al. 2011; Yu et al. 2018; Zhang et al. 2015). To date, the efficacy of these antibiotics was seriously compromised as evidenced by the frequent isolation of ampicillin-resistant $S$. suis strains from infected swine and human (Yu et al. 2018; Zhang et al. 2015). Therefore, novel and effective antimicrobial agents are indeed needed for the management of $S$. suis infection.

Rhodomyrtone is a principle antimicrobial compound found in ethanoic extract of medicinal plant Rhodomyrtus tomentosa (Aiton) Hassk. Leaves (Leejae et al. 2013; Limsuwan et al. 2009). Its antibacterial potency towards Gram-positive bacteria is equivalent to that of top available drugs. A molecular antibacterial mechanism underlining rhodomyrtone activity has been mostly elucidated. Integrative proteomic and metabolomic analyses revealed the effects of rhodomyrtone on pneumococcus carbohydrate metabolism. As a consequence, it caused reduction of capsule biosynthesis and formation (Mitsuwan et al. 2017). In addition, transcriptomic analysis of rhodomyrtone-treated methicillin-resistant Staphylococcus aureus (MRSA) showed that the compound had both immediate and late effects on MRSA gene expression. Bacterial cell cycle maintenance ( $s c d)$ and bacterial septum formation ( $f t s Z)$ 
appeared among 35 down-regulated genes (Sianglum et al. 2012). Furthermore, effects of rhodomyrtone on MRSA cell wall alterations, abnormal septum formation, and aberrant cell morphology have been visualized by transmission electron microscopy (Sianglum et al. 2011; Sianglum et al. 2012). Recently, it has been demonstrated that rhodomyrtone treatment as early as 30 min could increase MRSA membrane permeabilization, alteration of cell wall, and cell membrane integrity. As a consequence, cytoplasmic component leakage, cell lysis, and bacterial cells with undefined septum were observed (Sianglum et al. 2018). In silico analysis using molecular docking revealed that rhodomyrtone was able to bind to FtsZ and changed its conformation. This was further confirmed by the partial loss of GTPase activities and FtsZ polymerization in vitro (Saeloh et al. 2017). More recently, rhodomyrtone was clearly demonstrated to be a membrane-active compound15. Following the treatment, $S$. aureus membrane potential decrease immediately at low doses resulted in releasing of ATP and cytoplasmic protein without pore-formation effect (Saising et al. 2018). Other workers demonstrated increase in membrane fluidity and collapsed membrane potential in Bacillus subtilis as well as relocalization of seven membrane proteins (FtsA, DivIVA, MinD, PIsX, MreB, MurG and SdhA) trapping within the region of increased lipid fluidity (RIF) (Saeloh et al. 2018). Accumulation of high concentration of FtsA and other divisome proteins suggested that they might interfere with the dynamics of cell division complex that need to position at midcell area in timely and orderly manner. However, it has not yet known how these structural and physical changes as well as membrane potential collapsed directly affected the mechanisms of cell division or changes in cell morphology.

Chromosome or nucleoid segregation is an efficient process which ensures the bacterial daughter cells inherit genetic materials (Hajduk et al. 2016; Lewis 2001). Nucleoid segregation mechanism was proposed that it could be driven by the forces of bacterial general processes such as DNA replication and transcription and/or DNA-interacting proteins (Dworkin and Losick 2002; Toro and Shapiro 2010). ParABS system has been documented to play an important role in bacterial nucleoid segregation (Kjos and Veening 2014; Lewis 2001; Toro and Shapiro 2010). It consists of ParA, a walker type ATPase, and ParB, partitioning protein that bind to the specific DNA sequences, parS-sites, located at proximal to ori region. B. subtilis possesses completed partitioning system (Ireton et al. 1994; Wang et al. 2014) while Streptococcus pneumoniae carries only ParB protein and parS-sites (Attaiech et al. 2015; Kjos and Veening 2014). The absence of ParB in both organisms resulted in significant nucleoid segregation defect, leading to 1-4\% anucleated cells (Kjos and Veening 2014; Lee et al. 2003; Minnen et al. 2011). In addition, disruption of pneumococcus transcription by rifampicin or streptolydigin treatment resulted in nucleoid segregation defects (2-3\% anucleated cells) (Kjos and Veening 2014). Other antibiotics such as quinolone and $A 22$, inhibitors of bacterial cell wall protein, MreB, have been demonstrated to inhibit nucleoid segregation in Escherichia coli (Kruse et al. 2003). This study spotlights on antibacterial mechanism of rhodomyrtone involves the disruption of bacterial nucleoid segregation checkpoint leading to cell division defects.

\section{Materials And Methods}

\section{Bacterial strains, plasmids, and growth conditions}


S. suis reference strain $\mathrm{P} 1 / 7$ and recombinant $S$. suis carrying parB:: gfp were grown on Columbia blood agar plate supplemented with $5 \%$ red cells (BA) at $37^{\circ} \mathrm{C}$ under $5 \% \mathrm{CO}_{2}$ for 24 hours. A single colony was inoculated into Todd-Hewitt broth (THB) and incubated at $37^{\circ} \mathrm{C}, 5 \% \mathrm{CO} 2$ overnight. E. coli DH5a was used as a host for cloning and plasmid propagation. Strains were grown in Lubria-Bertani (LB) broth and agar at $37^{\circ} \mathrm{C}$ and supplemented with spectinomycin $(100 \mu \mathrm{g} / \mathrm{ml})$ when required.

\section{Construction of recombinant $S$. suis carrying pSET4s::parB::gfp}

In order to visualize nucleoid segregation, S. suis strain P1/7 carrying gfp fusion to 3'- end of parB gene was constructed such that ParB expression was driven using its endogenous promoter. The four overlap extension primers (Additional file: Table S1) were designed to fuse gfp coding sequence to the 3'-end of parB. The $p a r B / g f p$ amplicon was purified to use as a megaprimer to amplified parB:::gfp fusion amplicons. After several round of thermocycles, the outer primers, UsparB- F/ DsparB-R were added to the reaction and thermocycles were continued to 35 cycles. The plasmid DNA of pSET4s, thermosensitive suicide vector, and overlap extension PCR product, parB::gfp, were purified and endonuclease digestion with $S p h l$ and $B a m H$. The digested vector and amplicon were ligated and transformed into competent E. coli DH5a host. E. coli transformant carrying pSET4s::parB::gfp was selected on LB agar supplemented with $100 \mu \mathrm{g} / \mathrm{ml}$ spectinomycin. The $E$. coli clones carrying pSET4s::parB::gfp were screened by colony PCR using UsparB-F/DsparB-R and pSET4s-F/R primer pairs (Additional file: Table S1). The correct parB::gfp fusion was verified by DNA sequencing analysis. Competent $S$. suis cells were prepared by the addition of competence-inducing peptide (ComS), as previously described (Zaccaria et al. 2014). The purified pSET4s.:parB::.gfp plasmid was then transformed into $S$. suis. The recombinant $S$. suis carrying pSET4s:::parB:::gfp was selected on THB supplemented with $50 \mu \mathrm{g} / \mathrm{ml}$ spectinomycin. The presence of parB::gfp was detected by PCR and expression of ParB-GFP in recombinant $S$. suis was visualized by epifluorescence microscopy (Olympus BX53 microscope).

\section{Determination of rhodomyrtone minimum inhibitory concentration (MIC) and minimum bactericidal concentration (MBC) against S. suis}

Overnight cultures were used to adjust the turbidity ca. $1.5 \times 10^{8} \mathrm{CFU} / \mathrm{ml}$ using McFarland standard no. 0.5. The bacterial suspension was further adjusted in fresh Muller Hilton broth (MHB) to reach ca. $10^{6}$ $\mathrm{CFU} / \mathrm{ml}$. The MIC and MBC values of purified rhodomyrtone against $S$. suis were determined using broth microdilution method according to CLSI guidelines (CLSI 2018). In brief, rhodomyrtone was dissolved in $100 \%$ DMSO and two-fold serially diluted in MHB in wells of 96- wells microtiter plate to generate a final concentration ranging from 128 to $0.0625 \mu \mathrm{g} / \mathrm{ml}$. An equal volume $(100 \mu \mathrm{l})$ the bacterial suspension ( $c a$. $10^{5} \mathrm{CFU}$ ) was added into each well and further incubated at $37^{\circ} \mathrm{C}$ under $5 \% \mathrm{CO}_{2}$ for 18 hours. The MIC determination of rhodomyrtone against $S$. suis was carried out in triplicate wells. The MIC was interpreted follow the three separate experiments. Thereafter, $\mathrm{MBC}_{99}$ of $S$. suis was further determined by plating out on BA to enumerate the colonies.

\section{Time-kill assay}


The ca. $10^{5} \mathrm{CFU}$ S. suis was treated with MHB supplemented with rhodomyrtone at $2 \times(1 \mu \mathrm{g} / \mathrm{ml}), 1 \mathrm{x}$ $(0.5 \mu \mathrm{g} / \mathrm{ml}), 0.5 \times(0.25 \mu \mathrm{g} / \mathrm{ml}), 0.25 \times(0.125 \mu \mathrm{g} / \mathrm{ml})$, and $0.125 \times(0.0625 \mu \mathrm{g} / \mathrm{ml}) \mathrm{MIC}$ active compound and incubated at $37^{\circ} \mathrm{C}$. Samples were collected every hour for 8 hours and once at 24 hours. Surviving bacteria were enumerated on BA. A tube containing 1\% DMSO was used as a growth control. The experiment was performed in triplicates.

\section{Determination of GFP activity of $S$. suis carrying pSET4s::parB::gfp}

Recombinant S. suis carrying pSET4s.:parB::gfp expressing ParB-GFP was grown in THB at $37^{\circ} \mathrm{C}$ until an $\mathrm{OD}_{600 \mathrm{~nm}}$ reach to $\sim 0.2$. Cells were subsequently treated at 0.0625 to $1 \mu \mathrm{g} / \mathrm{ml}$ rhodomyrtone or $1 \%$ DMSO (negative control). Unless otherwise stated, samples were collected 15 min intervals and ParB-GFP signals were measured by using spectroUVmeter (Thermo Electron Corporation, USA).

\section{Investigation of $S$. suis nucleoid segregation dynamic by fluorescence microscopy}

Recombinant S. suis carrying pSET4s.:parB::gfp expressing ParB-GFP was grown until an OD $600 \mathrm{~nm} \sim 0.2$. Cells were subsequently treated at 0.0625 to $1 \mu \mathrm{g} / \mathrm{ml}(0.125$ to 2 x MIC) rhodomyrtone and collected every 15 min intervals. Rifampicin (RNA synthesis inhibition antibiotic), quinolone (DNA replication inhibition antibiotic) were used as $S$. suis nucleoid segregation inhibitors. 1 \% DMSO was a negative control. Cells were immobilized on a thin film of $1.2 \%$ agarose and immediately observed using an Olympus BX53 microscope equipped with a Photometrics CoolSNAP fx digital camera. Image acquisition was performed using ImageJ software and processed with Adobe Photoshop 6.0.

\section{Immunofluorescence microscopy}

Immunostaining was adapted from Morlot et al. (2003). Briefly, exponential $S$. suis carrying pSET4s::parB::gfp grown in the presence of $1 \mu \mathrm{g} / \mathrm{ml}$ rhodomyrtone $(2 \times \mathrm{MIC})$ or rifampicin or $4 \mu \mathrm{g} / \mathrm{ml}$ quinolone for $30 \mathrm{~min}$. Cells were harvested by centrifugation at $10,000 \times g$ for $5 \mathrm{~min}$, fixed in $4 \%$ paraformaldehyde for $15 \mathrm{~min}$ followed by $45 \mathrm{~min}$ incubation on ice. Cells were washed three times in PBS and resuspended in GTE buffer (50 mM glucose, $20 \mathrm{mM}$ Tris-HCl pH 7.5, $10 \mathrm{mM}$ EDTA) and treated with lysozyme (final concentration $0.1 \mathrm{mg} / \mathrm{ml}$ ). Cells were immediately transferred onto poly L-lysine coated cover slips, washed with PBS and air-dried. It was then soaked in methanol at $-20^{\circ} \mathrm{C}$ for 5 min, air dried and rehydrated with PBS. The cover glasses were blocked for $30 \mathrm{~min}$ with $2 \%(\mathrm{w} / \mathrm{v})$ bovine serum albumin in PBS (BSA-PBS), incubated for 1 hour with 1:200 dilutions of rabbit anti-FtsZ antibodies (kindly provided by Professor Cécile Morlot, Institut de Biologie Structurale (IBS), Grenoble, France) washed five times with PBS, and further incubated with Alexa fluor 594 conjugated goat anti-rabbit immunoglobulins G (Fermentus) in BSA-PBS. For visualization of bacterial chromosomal DNA, $1 \mu \mathrm{g} / \mathrm{ml}$ of Hoechst 33342 dye (Sigma) was included with the secondary antibody. Following the extensive washing with PBS, cover glasses were observed and photographed under a Leica DM IRB fluorescence microscope equipped with a $63 x \backslash$ Bertrand immersion objective and standard filter sets for visualizing DAPI, FITC and Alexa fluor 594. Images were captured with a DC350 F digital camera system (Leica) 
driven by the Qfluoro software package (Leica). Rabbit anti-FtsZ antibodies was omitted in the secondary antibodies control.

\section{Transmission microscopy}

Exponential S. suis grown in the presence or the absence of rhodomyrtone at $1 \mu \mathrm{g} / \mathrm{ml}(2 \times \mathrm{MIC})$ or $0.25 \mu \mathrm{g} / \mathrm{ml}(0.5 \times \mathrm{MIC})$ for $30 \mathrm{~min}$ and $120 \mathrm{~min}$, respectively. Cells were harvested by centrifugation at $10,000 \times g$ for $5 \mathrm{~min}$. The cells were washed twice, resuspended in PBS, and fixed with $2.5 \%$ glutaraldehyde in sucrose phosphate buffer (PB) overnight. Cells were then recovered by centrifugation, washed twice with PB and then fixed with 1\% osmium tetraoxide at room temperature for 1 hour. The samples were dehydrated with gradient ethanol solutions (30\% to $90 \%$ at 10 min intervals) and incubated twice in 100\% ethanol for 15 min. Bacterial cells were then embedded in Epon 812 resin, polymerized for 2 days, cut into $90 \mathrm{~nm}$-thin slices, placed on grid and counter stained with uranyl acetate and lead citrate. Cellular contents and morphology were observed at $200 \mathrm{~nm}$ magnification and photographed by a Hitashi H7000 transmission electron microscopy at department of Tropical pathology, Faculty of Tropical medicine, Mahidol University.

\section{Results}

\section{Identification of gene involving in Streptococcus suis nucleoid segregation}

In this study, DNA region involving in nucleoid segregation system of $S$. suis was identified from genome sequence of P1/7 reference strain (Genbank accession number NC_012925). S. suis nucleoid segregation system genes contained only parB and parS. S. suis parB was annotated as SSU_RS09915 locating in the vicinity of chromosomal origin of replication, oriC (Fig. 1). Approximately $3 \mathrm{~kb}$ region containing parB was amplified from genomic DNA of $S$. suis $\mathrm{P} 1 / 7$ and subjected to nucleotide sequencing. BlastX analysis (Additional file: Fig. S1) revealed that $S$. suis ParB were 765 nucleotides long. Its deduced amino acid sequence (254 residues) had 54\% identity to the well-characterized ParB from D39 S. pneumoniae (Genbank accession number NC_008533). S. suis ParB completely carried two conserved ParB motifs, DNA binding (amino acid residues 4 to 100), and activating ATPase activity (residue 7 to 95). Three stretches of $S$. suis parS consensus sequences, NGTTTCACGNNAAACN, were identified in an anticlockwise regions of $S$. suis oriC at $-2.8 \mathrm{kbp}\left(-0.5^{\circ}\right),-18 \mathrm{kbp}\left(-3.24^{\circ}\right)$, and $-9 \mathrm{kbp}\left(-12.42^{\circ}\right)$ (Fig. 1). The three sequences exhibited $92.19 \%$ identity to entire parS from Streptococcus spp. including S. pneumoniae (Additional file: Fig. S2). The data obtained in our study further emphasized that genetic components of nucleoid segregation system were highly conserved among Streptococcus spp. including S. suis.

\section{Dynamic of nucleoid segregation in Streptococcus suis}

In this study, to investigate $S$. suis nucleoid segregation, ParB-GFP (Green fluorescent protein) was used as a reporter to mark parS in order to indicate the location of the neighborhood oriC sequence. The recombinant ParB-GFP S. suis appeared as a bright green fluorescence spot within the cytoplasm of 
dividing $S$. suis cells reflecting the position of oriC region (Fig. $2 \mathrm{~b}$ ). The dynamic of $S$. suis nucleoid localization during exponential phase was shown in Fig. 2a-e. Green fluorescence dispersed indicated $S$. suis nucleoid did not yet enter the division cycle $(\mathrm{t}=0$, Fig. 2a). Fifteen minutes later, ParB-GFP signal of reporter strain exhibited as single foci representing the initiation of nucleoid replication $(t=15$, Fig. $2 b)$. At $30 \mathrm{~min}, \mathrm{~S}$. suis nucleoid was duplicated as two bright green ParB-GFP foci (or two oriC) in each cell pole of a single cell ( $t=30$, Fig. $2 \mathrm{c})$. The nucleoid segregation was completed and Z-ring started to constrict within $45 \mathrm{~min}(\mathrm{t}=45$, Fig. $2 \mathrm{~d})$. Septum were formed within one hour as each oriC was localized to newly generated daughter cells $(t=60$, Fig. $2 e)$. The data demonstrated that $S$. suis nucleoid segregation (i. e. timing from initiation of duplicated oriC to oriC mobilization to newly generated daughter cells) was approximately $30 \mathrm{~min}$, and $S$. suis cell division cycles (i. e. timing from initiation of duplicated oriC to beginning of the next round of oriC duplication) was $60 \mathrm{~min}$. These observations were further confirmed by the gradually increasing in GFP activity quantification during division cycle (Fig. 2, right column). Our finding demonstrated that $S$. suis nucleoid was rapidly replicated and completely segregated to each cell pole using three quarters of the duration of cell division cycle.

\section{Antibacterial activity of rhodomyrtone against Streptococcus suis}

The MIC and MBC of rhodomyrtone, rifampicin, and quinolone against wildtype parent P1/7 S. suis and isogenic ParB-GFP reporter strains were shown in Table 1. MIC and MBC values of rhodomyrtone ranged from 0.5 and $1 \mu \mathrm{g} / \mathrm{ml}$, which were equivalent to those of rifampicin, while MIC and MBC of quinolone were 2 and $4 \mu \mathrm{g} / \mathrm{ml}$, respectively. The antibacterial efficacy of rhodomyrtone was further determined by time-kill assay. The bactericidal activity of rhodomyrtone was concentration and time dependence. In ParB-GFP S. suis, three log-fold decrease in cell numbers was evident within 4 hours (Fig. 3b), compared with 3 hours in wildtype parent strain (Fig. 3a), following the treatment with $1 \mu \mathrm{g} / \mathrm{ml}$ rhodomyrtone.

Table 1 Minimal inhibitory concentration (MIC) and minimal bactericidal concentration (MBC) values of rhodomyrtone, rifampicin and quinolone

against Streptococcus suis wildtype strain P1/7 nd recombinant reporter strain ParB-GFP

\begin{tabular}{lcc}
\hline Antibacterial agents & \multicolumn{2}{c}{ Antibacterial activity $\mathrm{MIC} / \mathrm{MBC}(\mu \mathrm{g} / \mathrm{ml})$} \\
\cline { 2 - 3 } & $S$. suis wildtype strain P1/7 & S. suis recombinant strain ParB-GFP \\
\hline Rhodomyrtone & $0.5 / 1$ & $0.5 / 1$ \\
Rifampicin & $0.5 / 1$ & $0.5 / 1$ \\
\hline Quinolone & $2 / 4$ & $2 / 4$ \\
\hline
\end{tabular}

\section{Effects of rhodomyrtone on Streptococcus suis nucleoid segregation}

In order to investigate whether rhodomytone affected $S$. suis nucleoid segregation, recombinant $S$. suis ParB-GFP was treated with 0.0625 to $1 \mu \mathrm{g} / \mathrm{ml}$ rhodomyrtone. Fluorescent micrographs illustrated a 
successful nucleoid segregation with a mobilization toward cell poles in negative control, $1 \%$ DMSO treatment (Fig. 4a). Treatment with either $1 \mu \mathrm{g} / \mathrm{ml}$ rhodomyrtone (Fig. 4b) or rifampicin (Fig. 4c) for 30 min resulted in the partial segregation of nucleoid as they failed to mobilize to new cell pole indicating by non-segregated oriC (unnoticeable of separating ParB-GFP foci). In treatment with $4 \mu \mathrm{g} / \mathrm{ml}$ of quinolone, only single ParB-GFP focus was observed as a consequence of DNA replication inhibition by quinolone (Fig. 4d). In addition, the quantitative measurement of ParB-GFP signals for rhodomyrtone, rifampicin, and quinolone was significantly decreased since the initial exposure (Additional file: Table $S 2, t=0$ ) suggesting that rhodomyrtone is likely to produce stronger impact on ParB-foci dynamics than nucleoid duplication. The aberrant of nucleoid segregation led to the appearance of $0.3 \pm 0.2 \%$ of anucleated cells illustrated by absence of DNA staining by Hoechst 33342 at $30 \mathrm{~min}$ post $1 \mu \mathrm{g} / \mathrm{ml}$ rhodomyrtone treatment (Fig. 4b and Table 2, $t=30$ ). At this time point, no anucleated cells were found in treatment with sub-lethal concentrations of rhodomyrtone $(0.0625$ to $0.5 \mu \mathrm{g} / \mathrm{ml})$, moreover, the two foci of ParB-GFP or oriCs were appeared to successfully mobilize to each of cell poles indifference to that of $1 \%$ DMSOtreated cells. Furthermore, we found that rhodomyrtone treatment could generate $S$. suis anucleated cells in dose and time dependent manner as showed in Table $2.1 \mu \mathrm{g} / \mathrm{ml}$ rhodomyrtone treatment yielded significantly higher numbers of anucleated cell $(2.3 \pm 0.2 \%, 3.4 \pm 0.4 \%$ and $3.5 \pm 0.4 \%$ at 60,120 and $240 \mathrm{~min}$ post-treatment, respectively) ( $p$-values $<0.05$ ). The similar phenomenon was also observed in treatment with sub-lethal concentrations of rhodomyrtone. Furthermore, $0.125 \mu \mathrm{g} / \mathrm{ml}$ rhodomyrtone was the lowest concentration to produce a significantly number of anucleated cells (Table $2, t=240, p$-values $<0.05$ ). Anucleated cells found in positive control agents, rifampicin and quinolone treatment were also gradually increased in time and concentration dependent manner (Table 2).

Table 2 Percentage of average anucleated cell number in rhodomyrtone treated-recombinant Streptococcus suis ParB-GFP ${ }^{\mathrm{a}}$

\begin{tabular}{|c|c|c|c|c|c|c|c|c|}
\hline \multirow[t]{3}{*}{ Time $(\mathrm{t})$ in minute } & \multicolumn{8}{|c|}{ Percentage of average anucleated cell number (\%) } \\
\hline & \multirow[t]{2}{*}{$1 \%$ DMSO } & \multicolumn{5}{|c|}{ Rhodomyrtone $(\mu \mathrm{g} / \mathrm{ml})$} & \multirow{2}{*}{$\begin{array}{c}1 \text { pg/ml } \\
\text { Rifampicin }\end{array}$} & \multirow{2}{*}{$\begin{array}{c}4 \mu \mathrm{g} / \mathrm{ml} \\
\text { Quinolone }\end{array}$} \\
\hline & & 1 & 0.5 & 0.25 & 0.125 & 0.062 & & \\
\hline 0 & 0 & 0 & 0 & 0 & 0 & 0 & 0 & 0 \\
\hline 15 & 0 & 0 & 0 & 0 & 0 & 0 & 0 & 0 \\
\hline 30 & 0 & $0.3 \pm 0.2$ & 0 & 0 & 0 & 0 & $0.7 \pm 0.2 *$ & $0.9 \pm 0.2 *$ \\
\hline 45 & 0 & $0.3 \pm 0.2 *$ & 0 & 0 & 0 & 0 & $1.1 \pm 0.2^{*}$ & $2.1 \pm 0.2 *$ \\
\hline 60 & 0 & $2.3 \pm 0.2 *$ & $1.4 \pm 0.4^{*}$ & $0.7 \pm 0.2^{*}$ & $0.1 \pm 0.2$ & 0 & $4.1 \pm 0.6^{*}$ & $6.3 \pm 0.2^{* *}$ \\
\hline 120 & 0 & $3.4 \pm 0.4^{*}$ & $1.9 \pm 0.2 *$ & $0.7 \pm 0.2 *$ & $0.1 \pm 0.2$ & $0.1 \pm 0.2$ & $4.8 \pm 0.4^{*}$ & $6.4 \pm 0.2^{* *}$ \\
\hline 240 & 0 & $3.5 \pm 0.4 *$ & $2.1 \pm 0.2^{*}$ & $1.3 \pm 0.2 *$ & $0.7 \pm 0.2 *$ & $0.3 \pm 0.2$ & $5.2 \pm 0.4^{*}$ & $6.6 \pm 0.4^{*}$ \\
\hline
\end{tabular}


a Cells were exposed to 0.062 to $1 \mu \mathrm{g} / \mathrm{ml}$ rhodomyrtone, $1 \mu \mathrm{g} / \mathrm{ml}$ rifampicin, and $4 \mu \mathrm{g} / \mathrm{ml}$ quinolone. DNA was stained by Hoechst 33342 and visualized. Anucleated cells were determined by absence of Hoechst signal (blue). For each treatment, over 500 cells were counted. The results were shown as mean \pm SD of three independent experiments.

* The significant changes in anucleated cell numbers between different treatments and durations were compared to $1 \%$ DMSO negative control using the Student's t-test. Significant differences were indicated as * (p-values $<0.05)$ and ** (p-values $<0.001)$.

\section{Effects of rhodomyrtone on Streptococcus suis septum formation}

In order to further investigate the effect of rhodomyrtone on $S$. suis septum formation, septum position in rhodomyrtone-treated ParB-GFP S. suis was probed with anti-FtsZ antibody and visualized by fluorescence microscope. Immunofluorescence micrograph illustrated that in 1\% DMSO control (Fig. 5a, arrow), $S$. suis completely achieved nucleoid segregation and septum was definitely placed at midcell of the so-divided cells. In contrast, treatment with $1 \mu \mathrm{g} / \mathrm{ml}$ rhodomyrtone for $30 \mathrm{~min}$ (Fig. 5b, arrow), S. suis nucleoid exhibited partially segregated and defect septum formation. Although, FtsZ was polymerized and completely formed constricted Z-ring, its position was misplaced by shifting away from midcell. Aberration of Z-ring placement phenotypes such as the accumulated FtsZ protein at one cell pole or dispersed and shifted away from center were also found in rifampicin and quinolone treatment (Fig. 5c and $5 \mathrm{~d}$, arrows).

\section{Transmission electron microscopy}

S. suis cytoplasmic content and morphology following the rhodomyrtone treatment was further elucidated by using transmission electron microscopy. Electron micrographs clearly showed that a newly generated daughter cell harbored complete segregated nucleoid with midcell septum in 1\% DMSO-treated cells (Fig. 6a). Thirty minutes post-treatment with $1 \mu \mathrm{g} / \mathrm{ml}$ rhodomyrtone led to partially segregation of $S$. suis nucleoid and septum was formed either in front of or over (guillotine effect) the incompletesegregated nucleoid (Fig. 6b, arrow), resulting in anucleated or dead daughter cells (Fig. 6b). Cell lysis, multi-constriction of the cell membrane, asymmetrically septum formation with a consequence of asymmetric of cell division with nucleoid guillotine effects were found at 120 min post-treatment with $1 \mu \mathrm{g} / \mathrm{ml}$ rhodomyrtone (Fig. 6d to 6f). None of these abnormalities were observed in 1\% DMSO control cells (Fig. 6c). The results further confirmed that rhodomyrtone treatment resulted in defective cell division by both partial nucleoid mobilization to cell pole and interfering of Z-ring midcell-positioning.

\section{Discussion}

Antibacterial activity of rhodomyrtone against $S$. suis was in the same range $(0.5-2 \mu \mathrm{g} / \mathrm{ml})$ in other pathogenic Gram-positive bacteria such as S. pneumoniae, S. pyogenes, S. aureus and B. subtilis (Limsuwan et al. 2011; Mitsuwan et al. 2017; Sianglum et al. 2011 and 2018). In this study, rhodomyrtone 
had antibacterial potency equivalent to common and effective drug used for treatment of $S$. suis infection such as penicillin, ampicillin and vancomycin. Moreover, $S$. suis showed lower tolerability to rhodomyrtone compared to relative Gram-positive bacteria such as $S$. aureus and 8 hours in S. pneumoniae. Treatment with $1 \mu \mathrm{g} / \mathrm{ml}$ rhodomyrtone remarkably decreased $S$. suis cell numbers greater than 3 log-folds within 4 hours, while the same effects were observed at 6 and 8 hours for $S$. aureus and 8 hours in S. pneumoniae, respectively (Sianglum et al. 2012; Sianglum et al. 2018). This information has further endorse rhodomyrtone as an effective narrow-spectrum antibacterial agent with low levels of MIC and MBC for treatment of Gram-positive bacterial infection. Furthermore, application in using rhodomyrtone as a drug for treatment of $S$. suis zoonotic infection or elimination of $S$. suis from pig respiratory tract and sanitization for prevention of zoonotic infection is warrant for further investigation.

Antibacterial of rhodomyrtone at molecular level was inconclusive. Previous studies showed rhodomyrtone changed the expression of proteins play role in bacterial cell cycle. ParABs system is known to play a crucial role in bacterial nucleoid segregation. Bioinformatics approaches revealed that ParABs profiles were unique to the type of bacteria and tend to cluster among phylogenetically related species and genera (Lee et al. 2003; Mohl et al. 2001). Nowadays, two closely related bacilli species, Caulobacter crescentus and $B$. subtilis has been used as ParABs nucleoid segregation studied models (Dworkin and Losick 2002; Wang et al. 2014; Zaccaria et al. 2014). While the cocci including Staphylococcus, Streptococcus, and Lactococcus genera carries ParB (Lee et al. 2003). In this study, it was found that $S$. suis also carried ParB protein and parSDNA sequences in an absence of parA similar to S. pneumoniae (Ireton et al. 1994; Wang et al. 2014). ParB from S. suis and S. pneumoniae were both highly similar to B. subtilis Spo0J, the nucleoid segregation promoting protein (Wang et al. 2014). In addition, phylogenetic analysis has shown that parS sites in a large number of bacteria locating near oriC region and highly conserved for their nucleotide sequences. Three putative chromosomal parS sites of $S$. suis were found and their sequence, genetic organization were resembling to parS sites on S. pneumoniae chromosome (Mohl et al. 2001). These data further emphasized that genetic components of nucleoid segregation system were highly conserve among Streptococci.

Nucleoid segregation is efficient process to ensure that each of bacterial daughter cells inherit genetic material (Hajduk et al. 2016; Reyes-Lamothe et al. 2012; Toro and Shapiro 2010). It has been shown to be driven by the forces of bacterial general bioprocesses such as DNA replication and transcription and/or DNA-interacting proteins (Attaiech et al. 2015; Ireton et al. 1994; Lewis 2001; Strahl and Hamoen 2010). In this study, by tracking of ParB-GFP fusion protein in $S$. suis cells during cell division cycle, it was demonstrated that $S$. suis cell division cycle spanned 60 min equivalent to that of $S$. pneumoniae. Following the completely segregation of nucleoid serving as the checkpoint, the septum formation was initiated and completed within 15 min to generate the two daughter cells of which carried a single nucleoid (chromosome), serving as a final checkpoint of cell division. Similar, to those pneumococcus (Ireton et al. 1994), S. suis nucleoid segregation was covered a majority of cell division duration. These data suggesting all cocci genera carrying ParBs may share the same duration and kinetic of cell division cycle. 
Dynamic of $S$. suis nucleoid segregation following the rhodomyrtone treatment was investigated only for the period of 4 hours due to their lack of viability after this period. Both fluorescence and EM micrographs (Fig. 4 and Fig. 6) confirmed the generation of daughter cells lacking of nucleoid presented as anucleated cells or possessed damage nucleoid from guillotine effects. The percentage of anucleated cells we found $(0.7 \pm 0.2$ to $3.5 \pm 0.4 \%)$ in the similar extent in pneumococci studied that either lacking of ParB or SMC functions led to in $4.7-7 \%$ guillotining nucleoid and $2-4 \%$ anucleated cells, while, inhibition of total cell transcription by inhibitors yielded 2-3\% anucleated cell (Attaiech et al. 2015; Ireton et al. 1994). These data indicated that partial interference of $S$. suis nucleoid mobility by rhodomyrtone seen in our study was also disrupt the checkpoint of $S$. suis cell division cycle. However, generation of minority of the anucleated cells were not shown to be an immediate consequence to the reduction cell number and dead. It has been demonstrated in growth rate determination of $p a r B$ and/or $s m c$ negative mutants S. pneumoniae in liquid media which bearing $2-4 \%$ anucleate cells that its cell number was not affect during log and stationary phases, however, the mutants exhibited slightly longer lag-phase compared to their isogenic wildtype. However, under transcription inhibitor treatment which was known to interfere nucleoid segregation, these $S$. pneumoniae mutants showed slower growth rate and hardly reached stationary phase (Ireton et al. 1994). Thus, combinatorial accumulations of anucleated cell populations, cell with guillotine nucleoids, and inability to divide cells would compromised the cell division thereby affect the cell number after multiple round of multiplication of which aggravated under the presence of other nucleoid segregation inhibitors. These phenomenon could also be applied to rhodomyrtone treatment in $S$. suis as the dramatic reduction in cell number was seen only after 4 hours for the highest concentration of rhodomyrtone treatment and this duration was extended in dose-dependent manners. These might due to the combinatorial effects of rhodomyrtone on nucleoid segregation and loss of function of other proteins trapped in RIF (Saeloh et al. 2018). Therefore, the additional functional consequence of rhodomyrtone treatment on other protein which directly or indirectly involve in nucleoid segregation remains to be elucidated.

Recently, rhodomyrtone has been demonstrated as a membrane-active compound (Saeloh et al. 2017) causing bacterial membrane potential collapse and release of intracellular proteins such as ATP and GAPDH indicated that the compound disturbed the intracellular bacterial protein homeostasis. Furthermore, Saeloh et al. (2018) demonstrated that rhodomyrtone caused delocalization of membrane proteins correlated to cell size and shape defects in B. subtilis and S. aureus (Saising et al. 2018; Sianglum et al. 2018). Two important cell division proteins, DivIVA and FtsA were known to associate with FtsZ during the septum formation as a final step of cell division. In S. pneumoniae, DivIVA protein has been proposed to play a role in the control of division site selection by ensuring FtsZ positioning at midcell compensating the absence minCDE operon in this organism (Fadda et al. 2007; Ni et al. 2018). Pneumococcal DivIVA interacts not only cell division proteins (FtsZ, FtsA, and FtsK) but also homolog of nucleoid segregation protein Spo0J protein to cooperate both nucleoid segregation and septum formation (Fadda et al. 2007). Interestingly, the absence of divIVA gene in S. suis impaired cell growth and division evidenced by decreasing viable cell count, asymmetric cell division and aberrant of septum formation (Ni et al. 2018). Strikingly, rhodomyrtone-treated S. suis exhibited defect in both nucleoid 
segregation and position of septum formation leading to asymmetrical cell division resulting in anucleate mini-cells similar to that of finding in bacteria with div/VA gene mutation in pneumococci (Fadda et al. 2007). Rhodomyrtone treatment, although, trapping of large amount of FtsZ in RIFs, it did not seem to interfere FtsZ polymerization to form Z-ring in vivo but rather the interference on its position. Therefore, it is possible that interference of rhodomyrtone treatment on nucleoid segregation was probably a consequence of the accumulation of other membrane proteins involving in cell division such as DivIVA or FtsA in RIFs.

\section{Declarations}

\section{Author contributions}

P.S. conceived the project.

A.T., P.S., P.T., and J.T. designed the experiments.

A.T performed the lab experiments.

A.T. and P.S. analyzed the data.

P.S. and S.V. supervised the project, as well as manuscript editing.

A.T. and P.S. wrote the manuscript

\section{Funding information}

This research was funded by the Thailand Research Fund Senior Research Scholarship (Grant number RTA5880005) and the 2018-2019 fiscal year budget of the office of the National Research Council of Thailand to Thammasat University.

\section{Consent for publication}

All authors consent to publication.

\section{Conflict of interest}

All authors declare no personal or professional conflicts of interest, and no financial support from the companies that produce and/or distribute the drugs, devices, or materials described in this report.

\section{Availability of data and materials}

All datasets supporting the conclusion of this article are included within the article and its additional files

\section{Ethics approval and informed consent}

Not applicable. 


\section{References}

Attaiech L, Minnen A, Kjos M, Gruber S, Veening JW (2015) The ParB-parS chromosome segregation system modulates competence development in Streptococcus pneumoniae. mBio 6(4):e00662

Bartosik AA, Mierzejewska J, Thomas CM, Jagura-Burdzy G (2009) ParB deficiency in Pseudomonas aeruginosa destabilizes the partner protein ParA and affects a variety of physiological parameters. Microbiology 155(Pt 4):1080-1092

CLSI (2018) Methods for dilution antimicrobial susceptibility tests for bacteria that grow aerobically. 11th ed. CLSI standard M07. Clinical and Laboratory Standards Institute, Pennsylvania

Dworkin J, Losick R (2002) Does RNA polymerase help drive chromosome segregation in bacteria? Proc Natl Acad Sci U S A 99(22):14089-14094

Fadda D, Santona A, D'Ulisse V, Ghelardini P, Ennas MG, Whalen MB, Massidda O (2007) Streptococcus pneumoniae DivIVA: localization and interactions in a MinCD-free context. J Bacteriol 189(4):1288-1298

Hajduk IV, Rodrigues CD, Harry EJ (2016) Connecting the dots of the bacterial cell cycle: coordinating chromosome replication and segregation with cell division. Semin Cell Dev Biol 53:2-9

Halaby T, Hoitsma E, Hupperts R, Spanjaard L, Luirink M, Jacobs J (2000) Streptococcus suis meningitis, a poacher's risk. Eur J Clin Microbiol Infect Dis 19(12):943-945

Ireton K, Gunther NW 4th, Grossman AD (1994) spo0J is required for normal chromosome segregation as well as the initiation of sporulation in Bacillus subtilis. J Bacteriol 176(17):5320-5329

Kjos M, Veening JW (2014) Tracking of chromosome dynamics in live Streptococcus pneumoniae reveals that transcription promotes chromosome segregation. Mol Microbiol 91(6):1088-1105

Kruse T, Møller-Jensen J, Løbner-Olesen A, Gerdes K (2003) Dysfunctional MreB inhibits chromosome segregation in Escherichia coli. EMBO J 22(19):5283-5292

Lakkitjaroen, N, Kaewmongkol, S, Metheenukul, P, Karnchanabanthoeng, A, Satchasataporn, K, Abking, N, Rerkamnuaychoke W (2011) Prevalence and antimicrobial susceptibility of Streptococcus suis isolated from slaughter pigs in northern Thailand. Kasetsart J (Nat Sci) 45:78-83

Lee PS, Lin DC, Moriya S, Grossman AD (2003) Effects of the chromosome partitioning protein Spo0J (ParB) on oriC positioning and replication initiation in Bacillus subtilis. J Bacteriol 185(4):1326-1337

Leejae S, Taylor PW, Voravuthikunchai SP (2013) Antibacterial mechanisms of rhodomyrtone against important hospital-acquired antibiotic-resistant pathogenic bacteria. J Med Microbiol 62(Pt 1):78-85

Lewis PJ (2001) Bacterial chromosome segregation. Microbiology 147(Pt 3):519-526 
Limsuwan S, Hesseling-Meinders A, Voravuthikunchai SP, van Dijl JM, Kayser O (2011) Potential antibiotic and anti-infective effects of rhodomyrtone from Rhodomyrtus tomentosa (Aiton) Hassk. on Streptococcus pyogenes as revealed by proteomics. Phytomedicine 18(11):934-940

Limsuwan S, Trip EN, Kouwen TR, Piersma S, Hiranrat A, Mahabusarakam W, Voravuthikunchai SP, van Dijl JM, Kayser $O$ (2009) Rhodomyrtone: a new candidate as natural antibacterial drug from Rhodomyrtus tomentosa. Phytomedicine 16(6-7):645-651

Lun ZR, Wang QP, Chen XG, Li AX, Zhu XQ (2007) Streptococcus suis. an emerging zoonotic pathogen. Lancet Infect Dis 7(3):201-209

Minnen A, Attaiech L, Thon M, Gruber S, Veening JW (2011) SMC is recruited to oriC by ParB and promotes chromosome segregation in Streptococcus pneumoniae. Mol Microbiol 81(3):676-688

Mitsuwan W, Olaya-Abril A, Calderón-Santiago M, Jiménez-Munguía I, González-Reyes JA, Priego-Capote F, Voravuthikunchai SP, Rodríguez-Ortega MJ (2017) Integrated proteomic and metabolomic analysis reveals that rhodomyrtone reduces the capsule in Streptococcus pneumoniae. Sci Rep 7(1):2715 DOI:10.1038/s41598-017-02996-3

Mohl DA, Easter J Jr, Gober JW (2001) The chromosome partitioning protein, ParB, is required for cytokinesis in Caulobacter crescentus. Mol Microbiol 42(3):741-755

Morlot C, Zapun A, Dideberg O, Vernet T (2003) Growth and division of Streptococcus pneumoniae: localization of the high molecular weight penicillin-binding proteins during the cell cycle. Mol Microbiol 50(3):845-855

Ni H, Fan W, Li C, Wu Q, Hou H, Hu D, Zheng F, Zhu X, Wang C, Cao X, Shao ZQ, Pan X (2018) Streptococcus suis DivIVA protein is a substrate of Ser/Thr Kinase STK and involved in cell division regulation. Front Cell Infect Microbiol 8:85 DOI:10.3389/fcimb.2018.00085

Reyes-Lamothe R, Nicolas E, Sherratt DJ (2012) Chromosome replication and segregation in bacteria. Annu Rev Genet 46:121-143

Saeloh D, Wenzel M, Rungrotmongkol T, Hamoen LW, Tipmanee V, Voravuthikunchai SP (2017) Effects of rhodomyrtone on gram-positive bacterial tubulin homologue FtsZ. PeerJ 5:e2962

Saeloh D, Tipmanee V, Jim KK, Dekker MP, Bitter W, Voravuthikunchai SP, Wenzel M, Hamoen LW (2018) The novel antibiotic rhodomyrtone traps membrane proteins in vesicles with increased fluidity. PLoS Pathog 14(2):e1006876

Saising J, Nguyen MT, Härtner T, Ebner P, Al Mamun Bhuyan A, Berscheid A, Muehlenkamp M, Schäkermann S, Kumari N, Maier ME, Voravuthikunchai SP, Bandow J, Lang F, Brötz-Oesterhelt H, Götz F (2018) Rhodomyrtone (Rom) is a membrane-active compound. Biochim Biophys Acta Biomembr 1860(5):1114-1124

Page 14/21 
Segura M, Zheng H, de Greeff A, Gao GF, Grenier D, Jiang Y, Lu C, Maskell D, Oishi K, Okura M, Osawa R, Schultsz C, Schwerk C, Sekizaki T, Smith H, Srimanote P, Takamatsu D, Tang J, Tenenbaum T, Tharavichitkul P, Hoa NT, Valentin-Weigand P, Wells JM, Wertheim H, Zhu B, Gottschalk M, Xu J (2014) Latest developments on Streptococcus suis: an emerging zoonotic pathogen: part 1. Future Microbiol 9(4):441-444

Sianglum W, Srimanote P, Taylor PW, Rosado H, Voravuthikunchai SP (2012) Transcriptome analysis of responses to rhodomyrtone in methicillin-resistant Staphylococcus aureus. PLoS One 7(9):e45744

Sianglum W, Srimanote P, Wonglumsom W, Kittiniyom K, Voravuthikunchai SP (2011) Proteome analyses of cellular proteins in methicillin-resistant Staphylococcus aureus treated with rhodomyrtone, a novel antibiotic candidate. PLoS One 6(2):e16628

Sianglum W, Saeloh D, Tongtawe P, Wootipoom N, Indrawattana N, Voravuthikunchai SP (2018) Early effects of rhodomyrtone on membrane integrity in methicillin-resistant Staphylococcus aureus. Microb Drug Resist 24(7):882-889

Strahl H, Hamoen LW (2010) Membrane potential is important for bacterial cell division. Proc Natl Acad Sci U S A 107(27):12281-12286

Toro E, Shapiro L (2010) Bacterial chromosome organization and segregation. Cold Spring Harb Perspect Biol 2(2):a000349

Wang X, Montero Llopis P, Rudner DZ (2014) Bacillus subtilis chromosome organization oscillates between two distinct patterns Proc Natl Acad Sci U S A 111(35):12877-12882

Wertheim HF, Nghia HD, Taylor W, Schultsz C (2009) Streptococcus suis: an emerging human pathogen. Clin Infect Dis 48(5):617-625

Yu Y, Fang JT, Zheng M, Zhang Q, Walsh TR, Liao XP, Sun J, Liu YH (2018) Combination therapy strategies against multiple-resistant Streptococcus suis. Front Pharmacol 9:489

Zaccaria E, van Baarlen P, de Greeff A, Morrison DA, Smith H, Wells JM (2014) Control of competence for DNA transformation in Streptococcus suis by genetically transferable pherotypes. PLoS One 9(6):e99394

Zhang C, Zhang Z, Song L, Fan X, Wen F, Xu S, Ning Y (2015) Antimicrobial resistance profile and genotypic characteristics of Streptococcus suis capsular type 2 isolated from clinical carrier sows and diseased pigs in China. Biomed Res Int 2015:284303

\section{Figures}




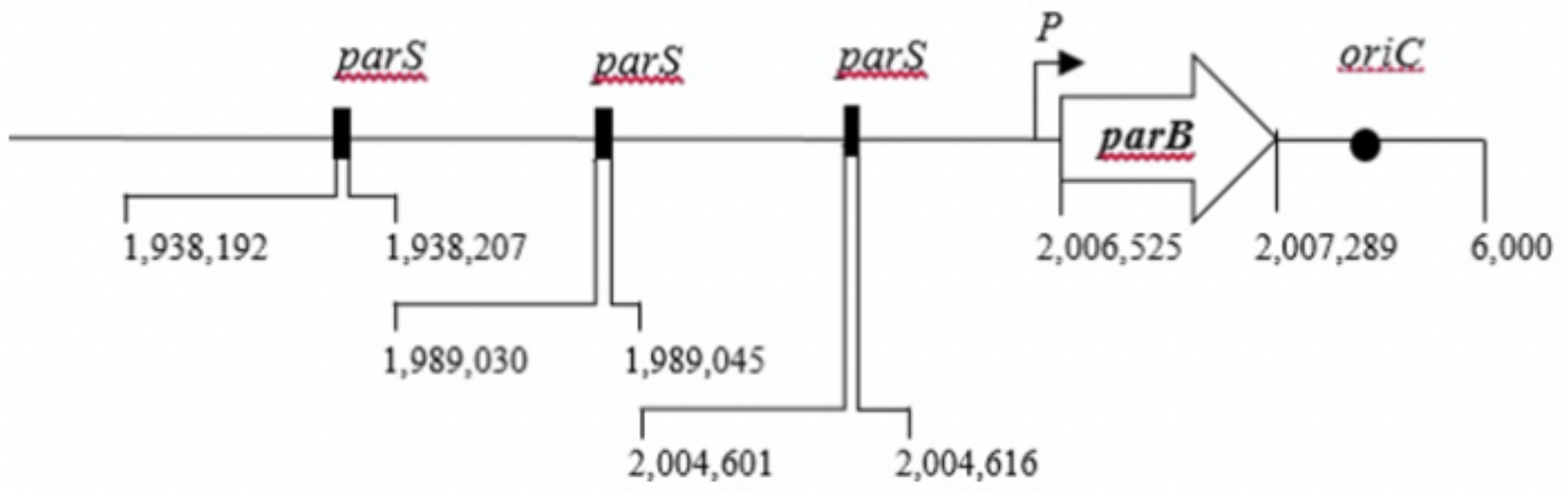

\section{Figure 1}

Schematic diagram represent genetic organization of Streptococcus suis nucleoid segregation machinery. Locations of parB and smc genes (white block arrows), parS (black rectangles), putative promoter $(\mathrm{P})$, and oriC (black circles) were shown. The digits below figure indicated the number of nucleotide sequence in base pairs $(\mathrm{bp})$ 


\section{Time (t) in minute}

A. $t=0$
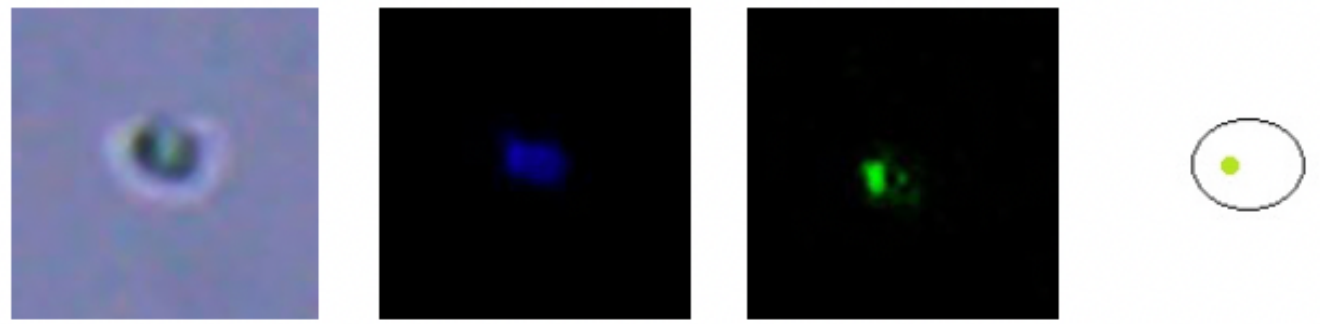

B. $t=15$
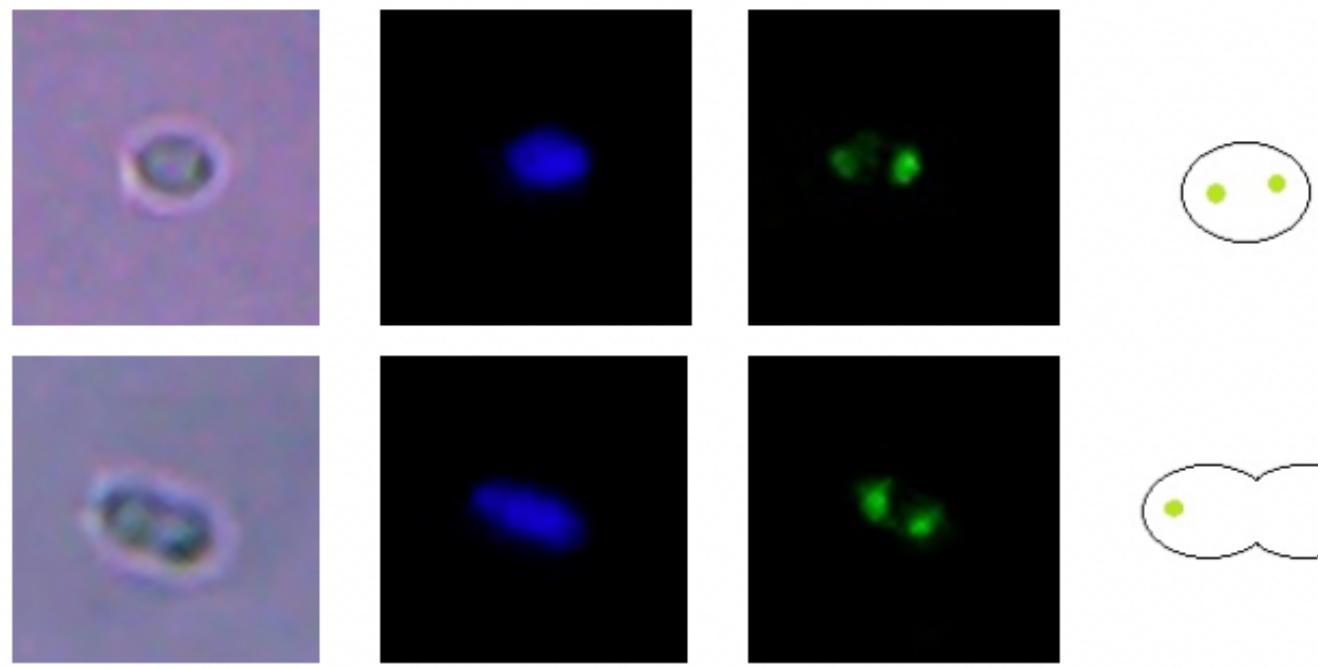

C. $\quad t=30$
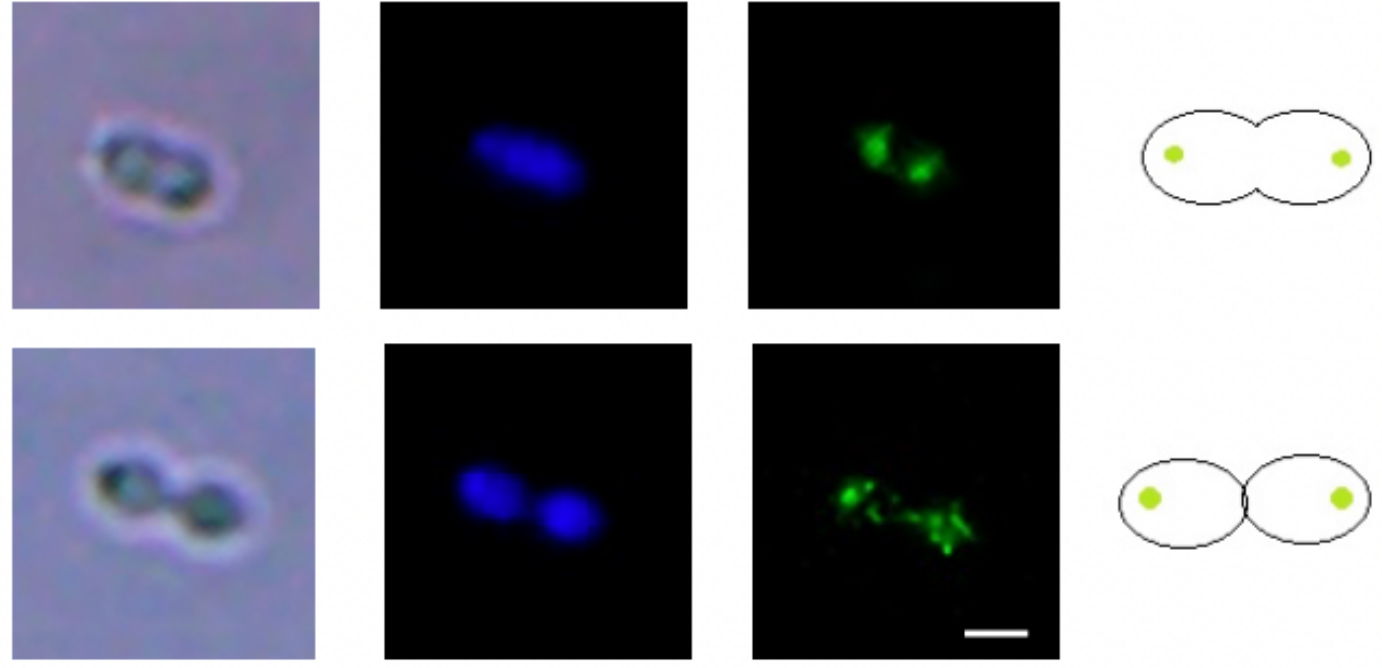

Figure 2

Localization of Streptococcus suis oriC (ParB-GFP) in representative cells at different stages of division was visualized by fluorescence microscopy. Panels $2 \mathrm{a}$ to $2 \mathrm{~d}$ were designated arbitrary time points of 15 minutes intervals ( $t=0$ to $60 \mathrm{~min}$ ). Recombinant $\mathrm{S}$. suis ParB-GFP cells were spontaneous expressed ParB-GFP (green) and were stained to visualize DNA (blue). Scale bar $=2 \mu \mathrm{m}$ 
A.

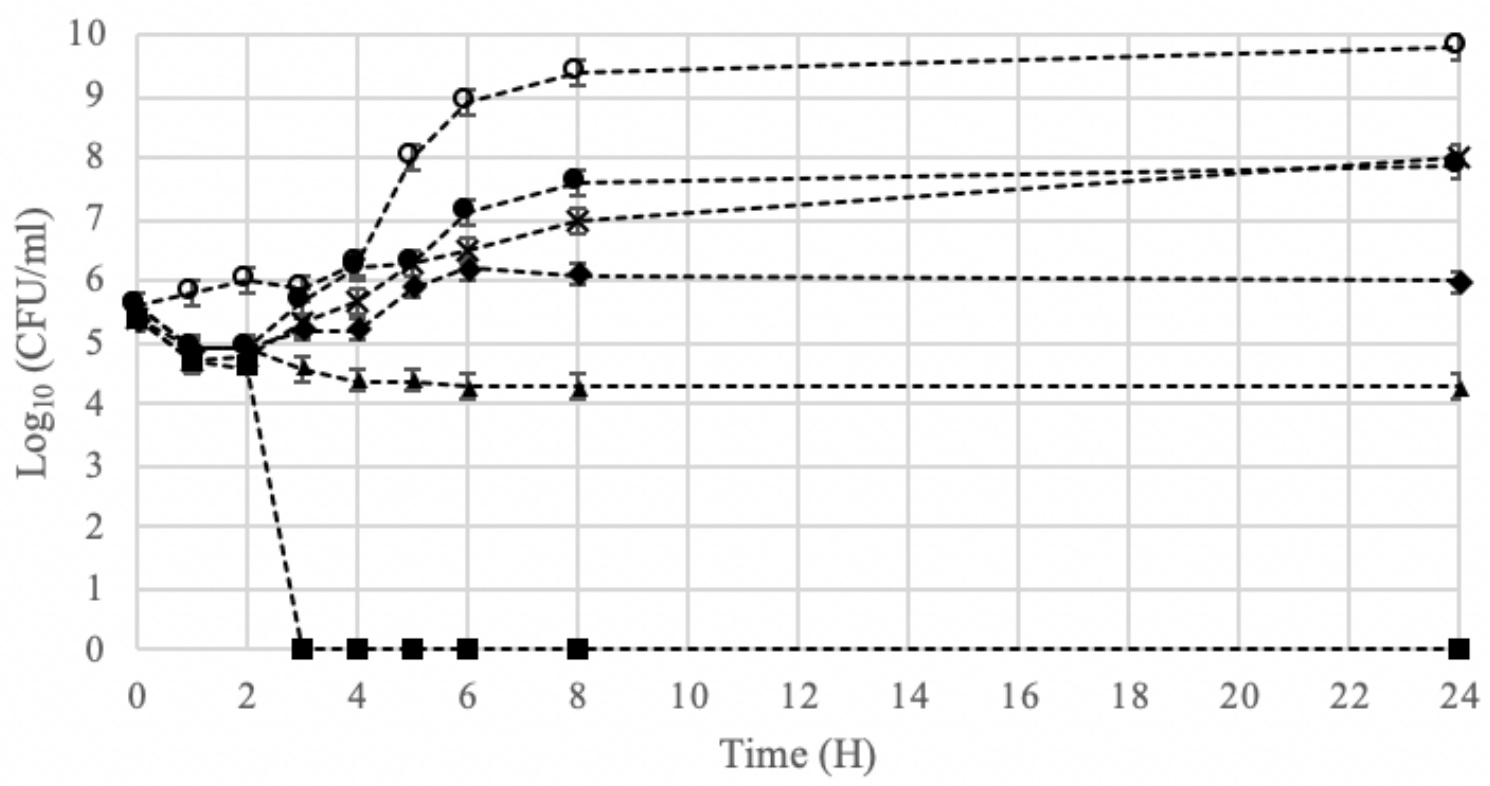

B.

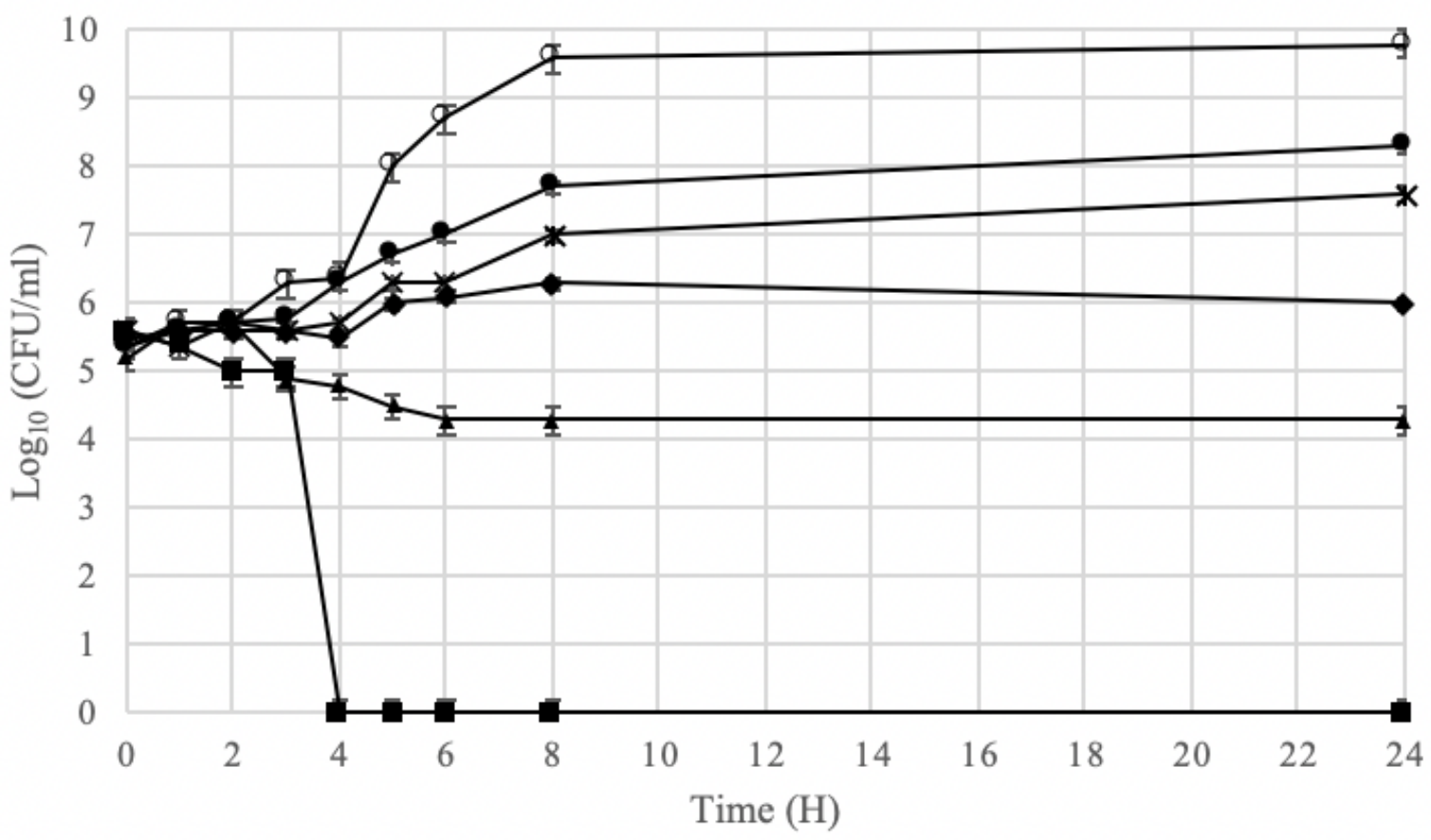

Figure 3

Time-kill curves of wildtype (a) and recombinant Streptococcus suis (ParB-GFP) (b) after treatment with rhodomyrtone at $1 \mu \mathrm{g} / \mathrm{ml}(\boldsymbol{\square}), 0.5 \mu \mathrm{g} / \mathrm{ml}(\boldsymbol{\Delta}), 0.25 \mu \mathrm{g} / \mathrm{ml}(\diamond), 0.125 \mu \mathrm{g} / \mathrm{ml}(\mathrm{x})$, and $0.0625 \mu \mathrm{g} / \mathrm{ml}(\boldsymbol{\bullet}) .1 \%$ DMSO (@) was used as a negative control. The results were shown as mean \pm SD of three independent cultures 


\section{A. $1 \% \mathrm{DMSO}$}

B. $1 \mu \mathrm{g} / \mathrm{ml}$

Rhodomyrtone

C. $1 \mu \mathrm{g} / \mathrm{ml}$

Rifampicin

D. $4 \mu \mathrm{g} / \mathrm{ml}$

Quinolone
Phase
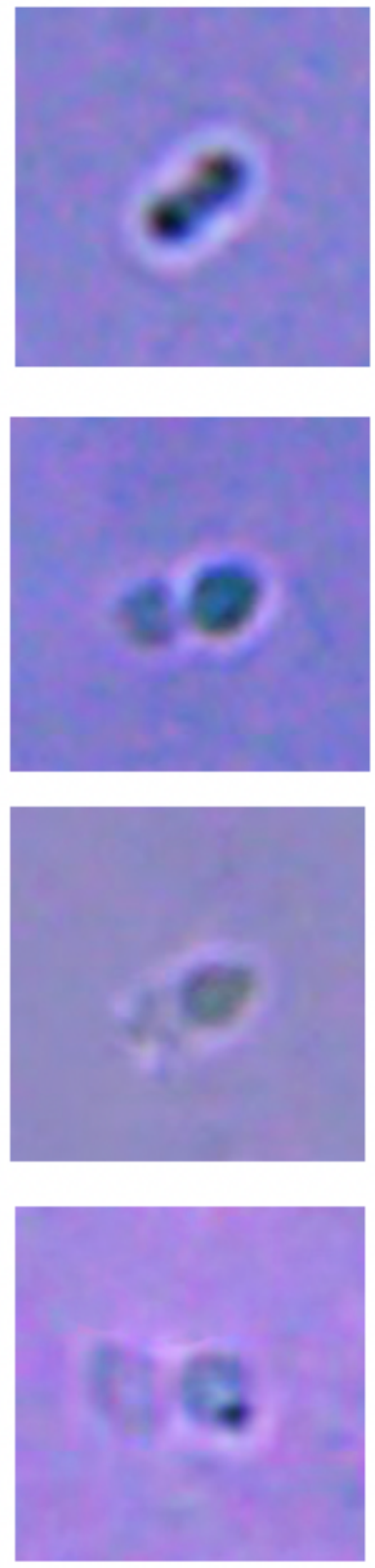

ParB-GFP
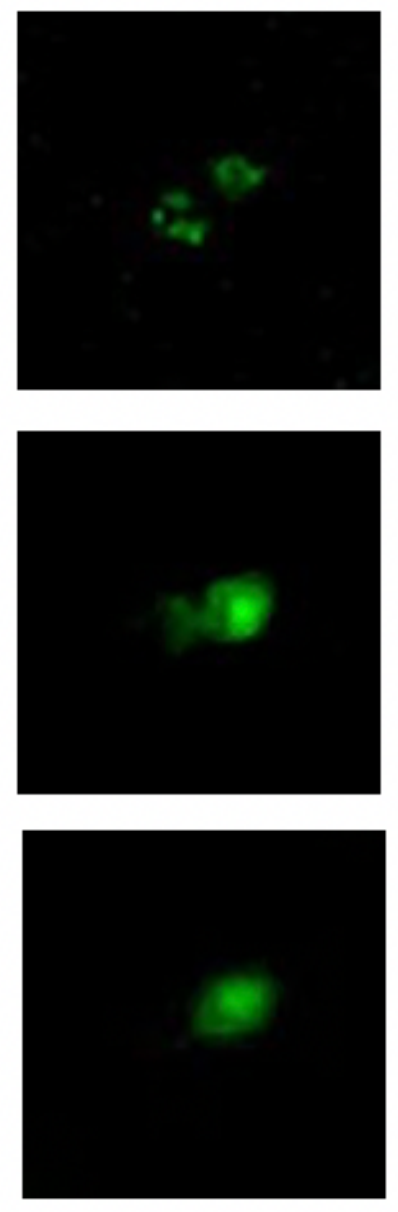

DNA
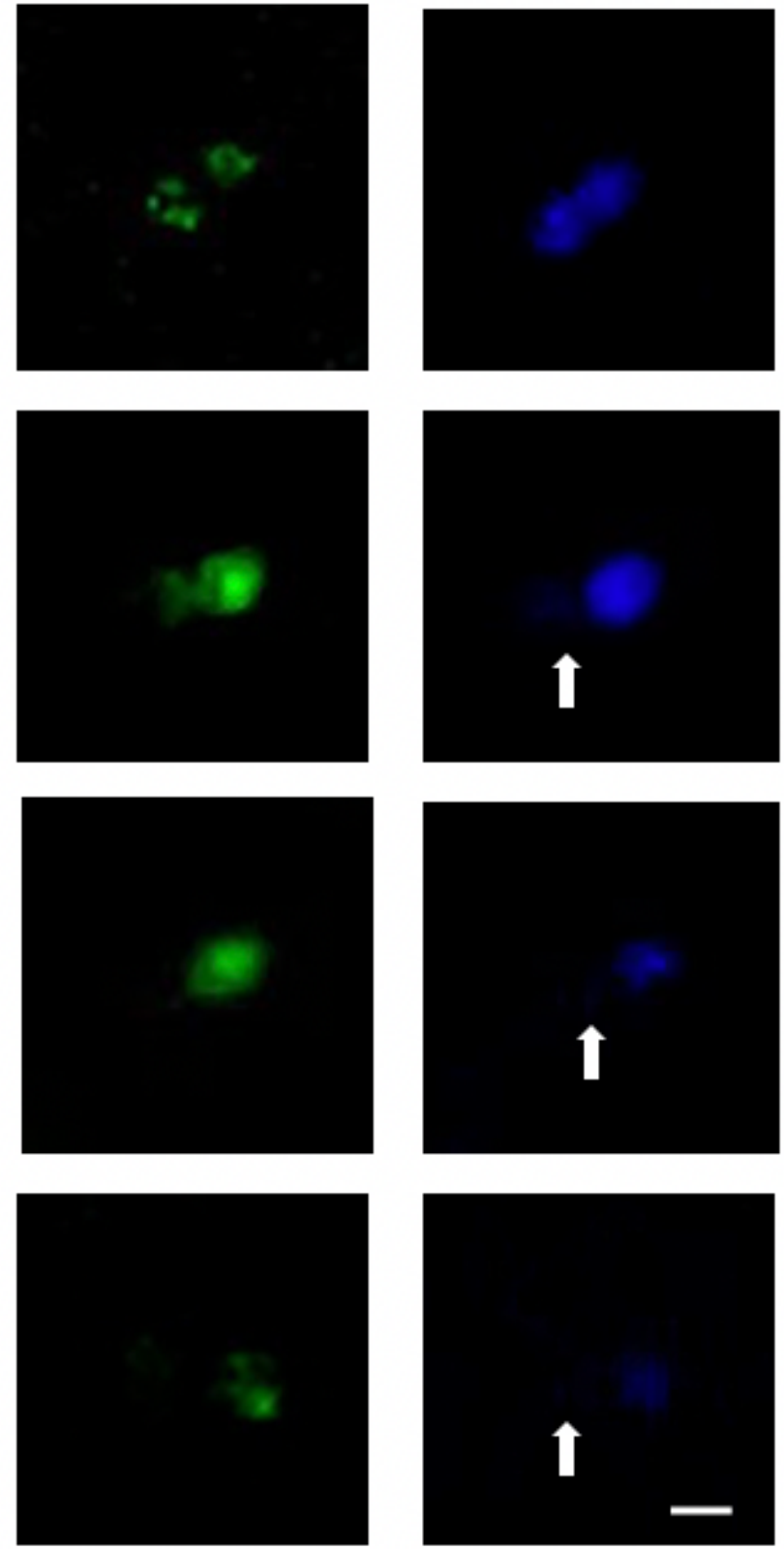

\section{Figure 4}

oriC localization (ParB-GFP) and the presence of anucleated cells following rhodomyrtone treatment was visualized by fluorescence microscopy. (a) $1 \%$ DMSO, (b) $1 \mu \mathrm{g} / \mathrm{ml}$ rhodomyrtone, (c) $1 \mu \mathrm{g} / \mathrm{ml}$ rifampicin and (d) $4 \mu \mathrm{g} / \mathrm{ml}$ quinolone for 30 minutes. Phase-contrast images (Phase), ParB-GFP (oriC) localization (green) and DNA (blue). Anucleated cells were indicated by white arrows. Scale bar $=2 \mu \mathrm{m}$ 


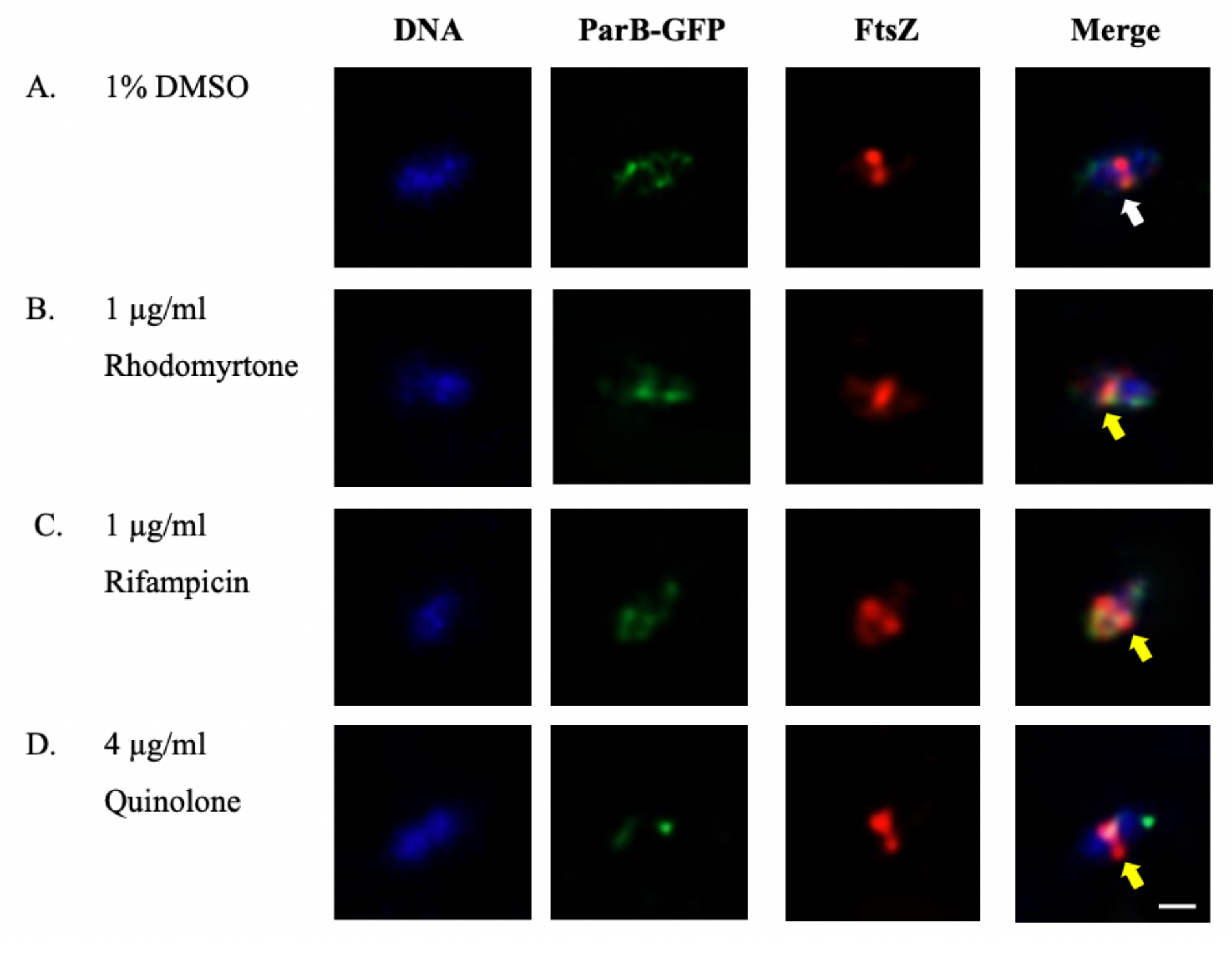

Figure 5

Effects of rhodomyrtone on recombinant Streptococcus suis (ParB-GFP) nucleoid and septum positioning was visualized by immunofluorescence microscopy. Representative $S$. suis after 30 minutes exposure to (a) $1 \%$ DMSO, (b) $1 \mu \mathrm{g} / \mathrm{ml}$ rhodomyrtone, (c) $1 \mu \mathrm{g} / \mathrm{ml}$ rifampicin, and (d) $4 \mu \mathrm{g} / \mathrm{ml}$ quinolone were shown. Localization of Hoechst 33342 stained DNA (blue), ParB-GFP (green), FtsZ (red) and overlaid of three fluorescence colors (Merge) were shown. Arrow indicated the characteristic of Z-ring (FtsZ) placement at midcell (a). Arrows indicated misplaced Z-ring shifting away from midcell found in rhodomyrtone, rifampicin, and quinolone-treated cells ( $b$ to $d$, respectively). Scale bars $=1 \mu \mathrm{m}$ 


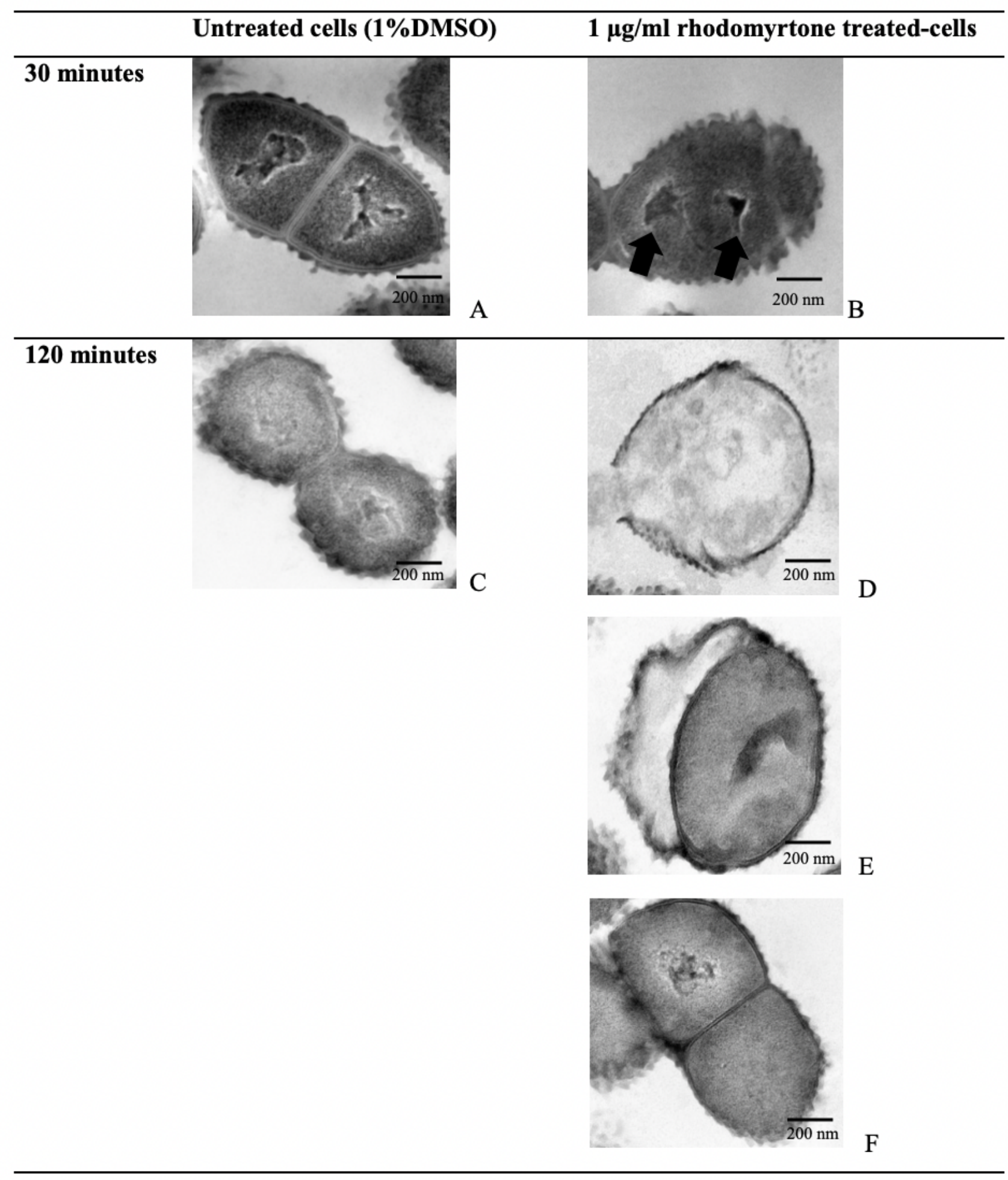

\section{Figure 6}

Transmission electron microscopy demonstrating the effects of rhodomyrtone on Streptococcus suis nucleoid segregation, septum formation and cell morphology. Recombinant S. suis ParB-GFP were treated with addition of $1 \mu \mathrm{g} / \mathrm{ml}$ of rhodomyrtone for $30 \mathrm{~min}(\mathrm{~b})$ and $120 \mathrm{~min}(\mathrm{~d}, \mathrm{e}$, and f). Cultures supplemented with 1\%DMSO for 30 min (a) and 120 min (c) were used as untreated control culture. Black arrow indicated incomplete-segregated nucleoid. Scale bar $=200 \mathrm{~nm}$ 